\title{
A arte de analisar poeira: uma rediscussão
}

\author{
Murilo Seabra $\underline{(1)}$
}

"O que está no âmago do comentador é o remorso: Eu queria ter tido essa idéia", era assim que começava a série de ataques pregadas em frente ao Departamento de Filosofia da Universidade de Brasília (UnB) no fim da década de 90 sob o título $A$ arte de analisar poeira: comentários sobre comentadores por um estudante que até então havia passado quase completamente desapercebido - preciso confessar, aquele estudante de cujos cantos da boca vertia a mais incontrolável espuma não era ninguém mais do que eu mesmo, que agora, poucos anos - ou talvez muitos depois do acontecido - mas em todo caso insuficientes para engendrar um julgamento neutro - atreve-se finalmente a analisá-lo sob um outro olhar.

Sobre o que aconteceu, não resta muito a dizer, nem adiantaria dizer algo agora, como nunca adiantou dizer coisa alguma - mas tornou-se claro para mim depois que fui vítima, não mais que vítima, em primeiro, da nulidade ao qual estava destinado por ser um mero aluno e um aluno brasileiro, sem um nome complexo que suscitasse atenção e respeito, em segundo, da ilusão de que as coisas poderiam mudar - da ilusão de que a situação - o destino - era conversável - da ilusão de que o Departamento de Filosofia - supostamente entupido de filósofos se mostraria minimamente sensível aos meus apelos. Nada - absolutamente nada do que eu queria saiu da potência ao ato, e dizer que a razão foi que se chegou a uma aprazível média aritmética - com concessões de ambos os lados - seria no mínimo insensato - mas já passou, já passou.

O que eu queria? Que fosse instituída uma disciplina onde os estudantes seriam incentivados a redigir suas próprias idéias - amparados pelas fartas leituras, pela experiência e pelo estímulo dos professores - mas a ridícula objeção de que não se saberia como proceder na hora da avaliação bastou para bloqueá-la - e também uma disciplina onde os professores exporiam e discutiriam suas próprias idéias com os estudantes - que poderiam ganhar muito em flexibilidade e detalhamento pelas inflexões de cérebros frescos e pouco viciados - uma sugestão que não encontrou apoio, como também suscitou um verdadeiro horror - talvez porque só dois ou três professores de todo o quadro pareciam qualificados para ministrá-la.

Um deles escreveu na época um texto chamado "Murilo's paradox". Que era: se todo mundo apenas escrever - se todos os filósofos se tornarem filósofos como Wittgenstein, com mais outputs do que inputs - chegar-se-á na curiosa situação de não sobrar ninguém para ler. O que esvaziará de sentido o próprio trabalho de escrever. É preciso então decepar os testículos do pai - como Cronos fez a Urano para que ele cesse um pouco de procriar. O paradoxo tem o mérito de refrear as pretensões dogmáticas e absolutistas que exalavam da forma desesperada - $e$ espumante - como eu defendia as minhas idéias. No entanto, no contexto geral da história, não conseguiu encontrar ocasião para desempenhar sua função - porque não houve nenhum excesso - na verdade, não houve nada - para que refreasse. 
O reverso do paradoxo - que eu poderia chamar de "paradoxo de Borges" - seria: se todos os filósofos se tornassem de repente apenas leitores - digamos, como Hacker e Malcom para Wittgenstein - chegar-se-ia na situação de não haver material para ler. Estaríamos ainda hoje comentando o que restou de Tales de Mileto - ou talvez, se Tales houvesse também seguido o dizer à risca, nem a água, mas apenas: o nada. Contudo, esse lado do paradoxo, o lado no qual eu insistia, não assustava os professores do Departamento de Filosofia - não faltam Tales, Platões, Aristóteles, Husserls, Russells e Wittgensteins sobre os quais escrever.

Os dois paradoxos inauguram um espaço de discurso, cada um limitando-o por um lado: num extremo, a impossibilidade de apenas escrever, sem ler; no outro extremo, a impossibilidade de apenas ler, sem escrever. Se adicionarmos a esses dizeres um tanto circunspetos - e por isso mesmo paradoxais - as expressões 'em primeiro lugar', 'em segunda importância', 'mais do que' e 'menos do que', o espaço ganhará em complexidade - o caminho que vai de um extremo ao outro se alongará e o número de opinióes possíveis - de loci conceituais - em seu interior se alargará. Quanto mais distantes dos extremos nos colocarmos, mais nos livraremos das contradições que os afligem - ou melhor, mais assim parecerá. Porque se não estivermos postos exatamente no centro - onde o discurso se equilibra, se neutraliza e não diz nada - estaremos apenas aumentando a complexidade do extremo ao qual mais nos inclinamos - com vistas a dissolver as suas verdadeiramente insolúveis - contradições.

Parece-me hoje que $A$ arte de analisar poeira não conseguiu mais do que deslocar os professores do Departamento de Filosofia do extremo "ler, sem escrever" para o locus conceitual mais próximo - dependendo do caso, para "primeiro ler, depois escrever" ou para "sobretudo ler, embora também escrever". Acreditando terem chegado finalmente às posições certas - às opiniões verdadeiras - deram-se - não todos, é claro - por satisfeitos - e passaram a defender, cada um seu locus, sem perceber que todos - ou quase todos - apontavam no mesmo sentido: para o extremo "ler, sem escrever". O que achavam ser a solução era apenas a manutenção - sob uma forma um pouco mais sofisticada - das suas posições anteriores.

Mas o que importa - o que realmente diferencia um locus conceitual do outro - é o sentido para onde ele aponta. Todos os do lado "ler, sem escrever" não constituem mais do que reforços - do que apoios - ao extremo original do qual emergem. A questão não é a de descobrir um locus que seja suficientemente complexo para parecer certo e sim perceber que a adoção de um locus - exceto o locus neutro, central - é uma questão política: todos os loci do lado "ler, sem escrever", por mais sofisticados que sejam, em última instância sugerem exatamente isso: ler, sem escrever - ou: repensar, sem pensar - ou: reproduzir, sem produzir - ou: manter, sem gerar - ou: desenvolver as idéias dos outros, não as próprias idéias - ou: analisar a poeira alheia, sem deixar para análise alheia a própria poeira.

Bom, é isso - é preciso ter sempre em mente que para cada argumento há sempre um contra-argumento, o seu espelho, e que por mais comprometido com a verdade que o ocupante de um locus pareça estar, sua opção sempre se revelará 
em determinadas conseqüências práticas. O defensor de um locus um pouco mais complexo do que o "ler, sem escrever" está sem dúvida sob o manto do período colonial - no entanto, na medida em que sua mão segura com menos determinação a foice de Cronos, parece seguir numa direção mais sustentável. Que não é - certamente - escrever, sem ler. Mas simplesmente: fazer o que der vontade e gerar condições para que os outros também façam o que querem fazer.

(1) Mestrando em Filosofia pela Universidade de São Paulo. E-mail: muriloseabra@yahoo.co.uk 